Gut, 1985, 26, 928-934

\title{
Plasma cell infiltration of the small bowel: lack of evidence for a non-secretory form of alpha-heavy chain disease
}

\author{
N H GILINSKY, A S MEE, D W BEATTY, B H NOVIS, G YOUNG, \\ $S$ PRICE, L R PURVES, AND I N MARKS
}

From the Gastrointestinal Clinic, the Departments of Medicine, Paediatrics, Pathology and Chemical

Pathology, Groote Schuur Hospital and the Institute of Child Health, University of Cape Town, Cape Town, South Africa.

SUMmARY Eight patients with diffuse plasma cell infiltration of the small bowel who had the clinical features of immunoproliferative small intestinal disease (IPSID), but whose serum was negative for free alpha-heavy chains, were investigated for evidence of a non-secretory form of alpha-chain disease $(\alpha-C D)$. Molecular sieving and immunoblotting of serum, immunoperoxidase staining of biopsy specimens, and in vitro protein synthesis studies utilising an immunoprecipitation technique and polyacrylamide gel electrophoresis, failed to detect any new cases of $\alpha-C D$. Four of the eight cases were found to have diffuse intestinal lymphoma. The remaining four patients, who were unsuccessfully investigated for evidence of a significant abnormality in cellular immunity, have not developed detectable $\alpha$-CD protein or lymphoma over a mean of 143 months. Despite continuing exposure to possible environmental stimuli, it is concluded that not all cases of IPSID elaborate detectable $\alpha$-CD protein or evolve to lymphoma.

Immunoproliferative small intestinal disease (IPSID) invariably presents with a malabsorption syndrome resulting from a diffuse and extensive, predominantly plasma cell infiltration of the bowel. ${ }^{1}$ Most reported cases have originated from the Mediterranean region, Middle East, Iran, Iraq, Indian subcontinent and South Africa. The IPSID spectrum of disorders includes malignant conditions such as immunoblastic (Mediterranean-type) lymphoma, alpha-chain disease $(\alpha-C D)$ with or without associated lymphoma, and 'benign' conditions characterised by malabsorption with a dense lymphoplasmacytic infiltration of the bowel in patients without lymphoma, and in whom alpha-chains cannot be identified. ${ }^{2}$

It has been postulated that diffuse intestinal plasma cell infiltration resulting from possible antigenic stimulation leads in susceptible individuals to the eventual production of $\alpha$-CD protein; ${ }^{3}$ and this process may ultimately evolve to lymphoma. ${ }^{4}$ Although $\alpha$-CD protein has been found in the serum

Address for correspondence: Dr N H Gilinsky, Gastrointestinal Clinic, Groote Schuur Hospital, Observatory 7925, Cape Town, South Africa.

Received for publication 1 November 1984 in $20-64 \%$ of cases of IPSID,$^{56}$ it has been suggested that the vast majority of cases of IPSID are in fact $\alpha-\mathrm{CD} .^{7}$ The recent report of a nonsecretory form of $\alpha-\mathrm{CD}^{8}$ has prompted a reevaluation of the prevalence of $\alpha-C D$ in IPSID patients.

We have investigated patients with diffuse plasma cell infiltration (PCI) of the bowel in order to determine whether patients with PCI and malabsorption, but without evidence of IPSID-associated lymphoma (IAL) or free alpha-chains in their serum, ${ }^{9}$ have a non-secretory form of $\alpha-C D$. We have determined whether these patients have a deficit in cell-mediated immunity, as has been suggested, ${ }^{10}$ and whether all patients with IAL have evidence of $\alpha-C D$.

\section{Methods}

\section{PATIENTS}

Eleven patients (seven women, four men) were studied. All were screened at presentation and at six monthly intervals throughout their course for the presence of free alpha-heavy chains in the serum by a modification of the immunoselection technique of 
Radl. ${ }^{11} 12$ The main clinical data for each patient at presentation are shown in Table 1 . Three patients had confirmed $\alpha-C D$; one (GW) was untreated while another (TC) was in partial remission and asymptomatic with virtually normal histology. The third (CC) was in full remission and off all treatment for eight years. Four subjects had IAL without demonstrable $\alpha-C D$ protein in the serum. The remaining four patients had a dense plasma cell infiltrate of the bowel, and at the time of study had been followed for a mean of 9.2 years without the development of lymphoma or overt $\alpha-C D$. Over an additional 2.7 year period, patients with $\alpha$-CD and IAL were recruited into the study, but no change in status of the PCI subgroup (follow up period 11.9 years) was observed. Ten of the 11 patients $(90 \%)$ had biochemical evidence of malabsorption, and intestinal parasitic infestation was found in six $(54 \%)$.

\section{BIOPSIES}

Endoscopically obtained distal duodenal/jejunal biopsies were transported to the laboratory in buffered formalin and fixed for light microscopy. Villous architecture and cellular infiltrate was assessed and the presence of $\operatorname{IgA}, \operatorname{IgG}, \operatorname{IgM}$ and kappa and lambda chains evaluated by standard immunoperoxidase (PAP) techniques ${ }^{13}$ (Table 2). Other specimens were taken for homogenisation and tissue culture (see below).

\section{PROTEIN STUDIES}

Routine protein and immunoglobulin electrophoresis on serum was done according to standard techniques. The immunoselection plate method of $\mathrm{Radl}^{10}$ was used to detect the presence of free alpha-chains in serum, preserved jejunal juice, concentrated urine and biopsy homogenates. The serum of each patient was also analysed by molecular sieving on Sepharose AcA34 (LKB) and the fractions electrophoresed on polyacrylamide gradient gels $(5-15 \%)$. The alpha-chain antigen was identified by an immunoblotting technique ${ }^{18}$ and the molecular size determined from molecular weight markers run concurrently. The IgA content of the fractions was determined by a nephelometric method (Hoechst Nephelometer).

\section{TISSUE CULTURE}

Intestinal biopsies were incubated on a millipore raft in $2 \mathrm{ml}$ RMPI 1640 culture medium (Gibco, New York) with $10 \%$ fetal calf serum and $1 \mu \mathrm{Ci}$ each of ${ }^{14} \mathrm{C}$-labelled leucine, isoleucine, valine, lysine, and argenine (Amersham, UK) for 24 hours at $37^{\circ} \mathrm{C}$ in $5 \% \mathrm{CO}_{2}: 95 \% \mathrm{O}_{2}$. Two mM PMSF (phenyl-methylsulphonyl-fluoride) was added to the culture supernate, and particulate material removed by centrifugation. The biopsy was homogenised in $2 \mathrm{ml} 50 \mathrm{mM}$ Tris, $100 \mathrm{mM} \mathrm{KCL}$ buffer containing triton X100, $0.5 \%$ deoxycholate and $2 \mathrm{mM}$ PMSF and cellular debris removed by centrifugation at $90000 \mathrm{G}$ for two hours. Immunoprecipitation of radiolabelled $\operatorname{sIgA}$ from the culture supernate and cell lysate was achieved by the addition of $5 \mu \mathrm{l}$ of purified colostral sIgA and $60 \mu \mathrm{l}$ of anti-secretory IgA shown to be specific for alpha-heavy chains only. The precipitates containing the in vitro labelled newly synthesised $\operatorname{sIgA}$ were washed four times by centrifugation, first with Tris KCL buffer and then with sodium chloride. The immunoprecipitated material was solubilised by boiling under reducing conditions and electrophoresed on SDS 9\% polyacrylamide slab gels. ${ }^{15}{ }^{14} \mathrm{C}$-labelled marker proteins (Amersham, UK) were run in parallel with the samples. Following fixation and drying of the gels, autoradiographs were developed after 14 days incubation at $-80^{\circ} \mathrm{C}$.

Table 1 Presenting features

\begin{tabular}{|c|c|c|c|c|c|c|}
\hline Patient & Sex & $\begin{array}{l}\text { Age } \\
\text { (y) }\end{array}$ & Diagnosis & Symptoms and signs & $\begin{array}{l}\text { Biochemical } \\
\text { malabsorption }\end{array}$ & $\begin{array}{l}\text { Intestinal } \\
\text { infestation }\end{array}$ \\
\hline GW & $\mathbf{M}$ & 29 & $\alpha-\mathrm{CD}$ & Diarrhoea, weight loss & + & - \\
\hline TC & $\mathbf{M}$ & 17 & $\alpha-\mathrm{CD}$ & Diarrhoea, weight loss, vomiting, abdominal pain & + & Giardia lamblia \\
\hline $\mathrm{CC}$ & $\mathbf{F}$ & 16 & $\alpha-\mathrm{CD}+\mathrm{IAL}$ & Diarrhoea, pain, weight loss, abdominal mass & + & Ascaris lumbricoides \\
\hline JK & $\mathbf{F}$ & 17 & IAL & Diarrhoea, pain, weight loss, clubbing & + & - \\
\hline $\mathrm{JC}$ & $\mathbf{M}$ & 48 & IAL & Diarrhoea, weight loss, pain, clubbing & + & Giardia lamblia \\
\hline PF & $\mathbf{M}$ & 26 & IAL & Diarrhoea, weight loss, pain, vomiting, clubbing & + & - \\
\hline HA & $\mathbf{F}$ & 14 & PCI & Diarrhoea, ankle oedema & + & Giardia lamblia \\
\hline $\mathrm{CN}$ & $\mathbf{F}$ & 20 & PCI & Abdominal discomfort, ankle oedema & + & - \\
\hline $\mathrm{JJ}$ & $\mathbf{F}$ & 14 & PCI & Diarrhoea, pain, growth retardation, clubbing & + & $\left\{\begin{array}{l}\text { Entamoeba histolytica } \\
\text { Trichomonas hominis } \\
\text { Giardia lamblia }\end{array}\right.$ \\
\hline SN & $\mathrm{F}$ & 13 & PCI & Diarrhoea, growth retardation, leg ulceration & - & $\left\{\begin{array}{l}\text { Ascaris lubricoides } \\
\text { Trichomonas hominis }\end{array}\right.$ \\
\hline
\end{tabular}


Table 2 Histological features and immunoperoxidase evaluation of small bowel biopsies

\begin{tabular}{|c|c|c|c|c|c|c|c|}
\hline Patient & Histological features & $\begin{array}{l}\operatorname{Imm} m \boldsymbol{L} \\
\operatorname{Ig} A\end{array}$ & $\begin{array}{l}\text { roxidas } \\
\lg G\end{array}$ & $\begin{array}{l}\text { Iluation* } \\
\text { IgM }\end{array}$ & kappa & lambda & $\begin{array}{l}\text { Alpha-chains } \\
\text { (serum) }\end{array}$ \\
\hline GW & TVA+LPCI, most atypical & 0 & trace & 0 & + & trace & present \\
\hline \multirow[t]{2}{*}{ TC } & PVA+LPCI, atypical immunoblasts & +++ & 0 & 0 & 0 & + & present \\
\hline & Villi normal. Slight increase in plasma cells $\dagger$ & ++ & 0 & trace & 0 & trace & present \\
\hline $\mathrm{CC}$ & $\begin{array}{l}\text { TVA+PCI } \\
\text { Normal } \dagger\end{array}$ & $\begin{array}{l}+++ \\
++\end{array}$ & $\begin{array}{l}\text { trace } \\
+\end{array}$ & $\begin{array}{l}\text { trace } \\
+\end{array}$ & $\begin{array}{l}\text { trace } \\
++\end{array}$ & + & $\begin{array}{l}\text { present } \\
\text { absent }\end{array}$ \\
\hline JK & PVA+LPCI, lymphoma & + & 0 & 0 & + & + & absent \\
\hline $\mathrm{JC}$ & PVA + LPCI & ++ & trace & + & + & + & absent \\
\hline UB & PVA + LPCI, some atypical & ++ & 0 & trace & + & + & absent \\
\hline PF & TVA + LPCI, some atypical & +++ & trace & trace & + & ++ & absent \\
\hline HA & PVA+PCI & +++ & + & + & ++ & ++ & absent \\
\hline \multirow[t]{2}{*}{$\mathrm{CN}$} & FVA +PCI & + & 0 & + & ++ & ++ & absent \\
\hline & Villi normal. Slight increase in plasma cells $\dagger$ & ++ & + & + & ++ & ++ & absent \\
\hline $\mathrm{JJ}$ & TVA +PCI & +++ & + & + & + & + & absent \\
\hline SN & PVA+PCI & +++ & + & + & ++ & ++ & absent \\
\hline
\end{tabular}

* Scale 0 to +++ (subjective $).+$ At time of study, if different from presentation. TVA $=$ total villous atrophy, LPCI $=$ lymphoplasmacytic cellular infiltration, $\mathrm{PVA}=$ partial villous atrophy, $\mathrm{PCI}=$ plasmacytic cellular infiltration, $\mathrm{FVA}=$ focal villous atrophy.

\section{LYMPHOCYTE CULTURE}

Lymphocytes, isolated as previously described, ${ }^{16}$ were suspended in RPMI 1640 medium supplemented with $15 \% \mathrm{AB}$ or autologous serum. ${ }^{17}$ After six days incubation with $50 \mu \mathrm{g}$ of pokeweed mitogen (Gibco, New York) the cells were centrifuged, assayed for cell number and viability, then resuspended in $2 \mathrm{ml}$ of the same medium as for the biopsy cultures containing ${ }^{14} \mathrm{C}$-labelled amino acids. After a further 24 hours incubation at $37^{\circ} \mathrm{C}$, the supernatant fluid and the cells were separated and processed in an identical manner to the culture supernatant and cell lysate from the biopsy cultures.

\section{CELLULAR IMMUNITY}

Phytohaemagglutinin (PHA) and concanavalin A (Con A) stimulated lymphocyte transformation was measured by incorporation of ${ }^{14} \mathrm{C}$-thymidine into peripheral blood lymphocytes. ${ }^{18}$ T-cell numbers were determined by their rosetting with uncoated sheep red blood cells ${ }^{19}$ with the addition of 2 -amino ethylisothionromium bromide hydrobromide (AET) to stabilise the rosettes. Measurements of T-cells, $\mathrm{T}$-suppressor cells and T-helper cells were done using standard immunofluorescent techniques with commercial monoclonal antisera (OK $\mathrm{T}$ series: Ortho Diagnostics, USA) and fluorescent conjugated rabbit anti-mouse IgG antisera (Miles-Yeda, Israel).

\section{Results}

\section{BIOPSIES}

The abnormalities present on light microscopy at the time of the study reflected those found at presentation (Table 2) with the exception of three cases: patient $\mathrm{CC}$ had a completely normal jejunal mucosa eight years after treatment of $\alpha-C D$ with IAL; and the histology of patients TC and CN showed normal villi with a mild increase in plasma cells in the lamina propria only. These three were asymptomatic at the time of study and only TC was receiving medication (tetracycline). Cases GW, JK, UB and PF, in addition to a dense plasma cell infiltrate, had collections of atypical large lymphoid and plasmacytoid cells. These cells did not take up the immunoperoxidase stains - which were suggestive of $\alpha-C D$ in CC (at presentation only) and TC. Uptake was virtually nil during the active untreated phase of $\alpha-C D$ in patient $\mathrm{GW}$. The immunoperoxidase profile returned to normal after treatment.

\section{SERUM PROTEINS}

The serum albumin was low in 10 patients. Four had a raised $\alpha_{2}$ globulin, three had both raised $\alpha_{2}$ and $\beta$ globulins and one had a raised $\beta$ globulin only. Although TC, CC, HA, JJ and SN had raised IgA (normal $0.64-5.44 \mathrm{~g} / \mathrm{l}$ ) at presentation, only HA $(27.3 \mathrm{~g} / \mathrm{l})$ and $\mathrm{SN}(51.0 \mathrm{~g} / \mathrm{l})$ had raised levels at the time of study. Free alpha-heavy chains were demonstrable by immunoselection in the serum of patients GW and TC. This method, however, was unable to detect free alpha-chains in the concentrated urine specimens, biopsy homogenates or jejunal juice samples of their, or any of the other patients. The immunoblotting technique confirmed $\alpha-C D$ in GW and TC but was negative in the remainder. Large amounts of IgA polymers, dimers and higher polymers were found in the serum of $\mathrm{HA}$ and $\mathrm{SN}$ who had PCI with markedly raised serum IgA. This was confirmed by the molecular sieving technique (Fig. 1). 


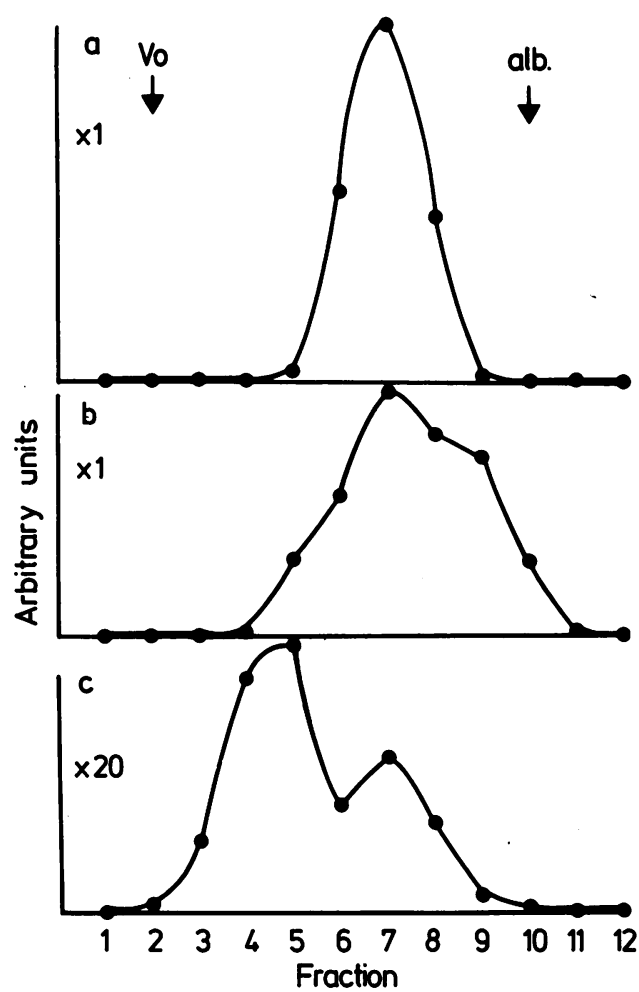

Fig. 1 Molecular sieving on AcA34 Sepharose. Void volume (Vo) and the position of albumin (alb) are indicated (a) Normal serum containing monomeric IgA. (b) An extra shoulder is present corresponding to alpha-heavy chain protein. (c) Plasma cell infiltrate (PCI) (patient HA)

-showing monomeric and polymeric IgA peaks.

Magnified 20x.

\section{TISSUE CULTURE}

In those patients with demonstrable free alpha chains in the serum, an abnormal labelled band with a molecular weight of approximately 41000 was specifically precipitated by anti-sIgA antibody (Figs. 2 and 3 ). In addition, radioactive labelled secretory piece and the heavy and light chains of reduced normal sIgA with molecular weights of approximately 80000,60000 and 24000 respectively were seen after polyacrylamide gel electrophoresis. The abnormal alpha-chain band in GW (Fig. 2) was more prominent in the culture supernate than in the cellular extracts. This band disappeared after treatment with tetracycline and corticosteroids and coincided with the reappearance of demonstrable light chain production. A very broad alpha-chain band was present in tissue culture of TC (Fig. 3). Although this was more prominent in the cellular extract, it was nonetheless also present in the culture

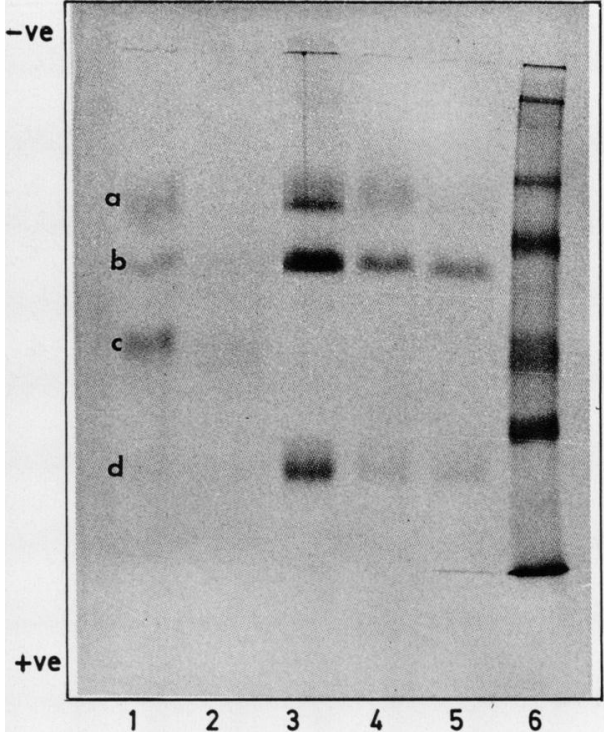

Fig. 2 Autoradiographs of tissue culture (patient GW) after immunoprecipitation and polyacrylamide gel electrophoresis. 1. Pretreatment supernate showing abnormal dense alpha-chain band. 2. Pretreatment cell lysate. 3. Control supernate. 4. Post-treatment supernate. 5. Post-treatment cell lysate. 6. Marker proteins from top to bottom as follows: Myosin (200 000 daltons), phosphorylase B (100 000 and 92500 daltons), ovalbumin (46 000 daltons), carbonic anhydrase (30 000 daltons) and lysozyme (14 300 daltons). (a) Secretory piece, (b) Normal heavy chains, (c) abnormal alpha-chain protein, (d) light chains. Note the post-treatment disappearance of alpha-chain band in 4 and 5 with reappearance of light chains.

supernatant. In the remaining patients no abnormal bands were detected either in the cellular or culture supernatant precipitates, and only the reduced components of normal sIgA were detected.

\section{LYMPHOCYTE CULTURE}

Analysis of the immune precipitates obtained from the peripheral blood lymphocyte cultures from the patients were all identical and showed only bands corresponding to normal IgA. No abnormal bands were found in lymphocyte cultures in those patients with free alpha-chains in the serum.

\section{CELLULAR IMMUNITY}

The results are shown in Table 3. In general, lymphocyte responses to transformation were normal or better than normal, except for patient HA. Results obtained with $\mathrm{AB}$ and autologous serum supplemented cultures were no different. T-cell 


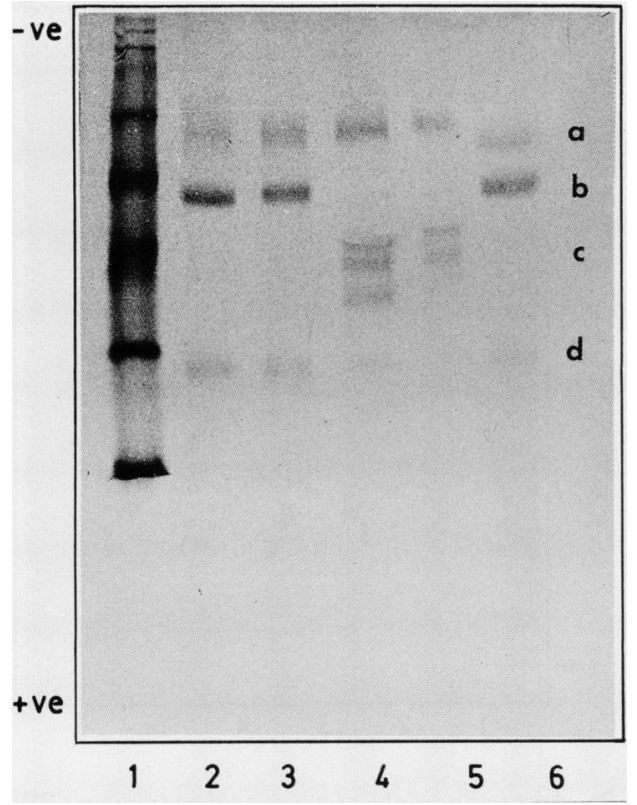

Fig. 3 Autoradiographs of tissue culture. Vertical columns and horizontal bands as for Fig. 2. 1. Marker proteins. 2. Cell lysate patient PF. 3. Supernate patient PF. 4. Cell lysate patient TC showing broad alpha-chain band. 5. Supernate patient TC with broad alpha-chain band. 6. Control supernate.

rosettes were slightly reduced in $\mathrm{HA}$ and $\mathrm{SN}$ as were the T-helper cells, and the T-suppressor cells were correspondingly slightly increased in these two cases.

\section{Discussion}

Early reports of diffuse intestinal lymphomas with malabsorption ${ }^{20}$ did not include protein studies, but subsequent studies have shown the presence of alpha-chains in many patients with the IPSID spectrum of disorders. ${ }^{56}$ Although the relationship between $\alpha-C D$, 'Mediterranean-type' lymphoma and PCI of the intestine is not clear, a number of cases of $\alpha$-CD evolving into lymphoma over a period of time have been observed. ${ }^{21}{ }^{22}$ Although it has been accepted that in the absence of detectable alpha-chains in the serum the diagnosis should not be ruled out until a search has been made at the cellular level, ${ }^{4}$ it is only recently that a non-secretory $\alpha-C D$ varient (by analogy with non-secretory myelomas) ${ }^{23}$ has been observed. ${ }^{824}$ This has increased speculation that perhaps all cases of IPSID are in fact either secretory or non-secretory forms of $\alpha-C D$

In the present series only those patients with demonstrable alpha-chains in the serum (GW and TC), showed synthesis of an abnormal $\alpha-C D$ protein band in biopsy cultures. In the case of GW, who had a dense cellular infiltrate, this band of precipitation was much more prominent in the culture supernatant than intracellularly. This is in accordance with the previously observed pattern of rapid export of proteins out of the cell and little or no intracellular storage. ${ }^{12}$ This band disappeared after treatment, parri passu with normalisation of the serum tests. On the other hand, the $\alpha-C D$ protein precipitate of TC, who was partially treated and whose biopsy showed only minimal abnormality, was more dense intracellularly than in the culture supernate. The explanation for this phenomenon is not clear but may be because of partial postsecretory proteolysis of the deleted fragment of heavy chain. Alternatively, one may postulate that a block in cellular export of the abnormal protein may be one of the early cellular consequences of intervention that is, a reversal of the normal sequence of events resulting from antibiotic therapy.

Alpha-chains could not be identified by a variety of intracellular or extracellular techniques in the remaining eight patients (four with PCI and four with IAL). Although it is possible that some of the methods used were not sufficiently sensitive to

Table 3 In vitro tests of cellular immunity

\begin{tabular}{|c|c|c|c|c|c|c|c|}
\hline \multirow[b]{2}{*}{ Patient } & \multicolumn{2}{|c|}{$\begin{array}{l}\text { Lymphocyte transformation } \\
\text { of control lymphocytes } \\
\text { in } A B \text { serum (\%) }\end{array}$} & \multicolumn{2}{|c|}{$\begin{array}{l}T \text {-cell sheep } R B C \\
\text { E rosettes }\end{array}$} & \multicolumn{2}{|c|}{$O K T T$-cell subsets } & \multirow[b]{2}{*}{$O K T 8$} \\
\hline & PHA & Con $A$ & Patient & Control & $O K T 3$ & $O K T 4$ & \\
\hline HA & 64 & 95 & $49 \%$ & $62 \%$ & $63 \%$ & $45 \%$ & $38 \%$ \\
\hline CN & 133 & 130 & $60 \%$ & $70 \%$ & $85 \%$ & $51 \%$ & $22 \%$ \\
\hline JJ & 132 & 70 & $72 \%$ & $58 \%$ & $88 \%$ & $58 \%$ & $29 \%$ \\
\hline SN & 167 & 232 & $51 \%$ & $58 \%$ & $59 \%$ & $32 \%$ & $34 \%$ \\
\hline
\end{tabular}

PHA = phytohaemagglutinin, Con $\mathrm{A}=$ concanavalin $\mathrm{A}, \mathrm{OKT} 3=$ total $\mathrm{T}$-cells (control mean $=62 \%$ ), OKT $4=\mathrm{T}$-Helper cells $($ control mean $=51 \%)$, OKT $8=\mathrm{T}$-Suppressor cells $($ control mean $=31 \%)$. 
recognise small amounts of $\alpha-\mathrm{CD}$ protein (immunofluorescent studies could not be used for a variety of reasons), even tissue culture and immunoprecipitation techniques failed to identify any new cases of $\alpha$-CD.

The failure of the immunoperoxidase stains to be taken up by many of the atypical cells would account for the inability of this method to diagnose $\alpha-C D$ in patient GW - which was confirmed by other methods. The active alpha-chain secreting cells were probably 'crowded out' by the mass of non-alphachain producing atypical cells, and may possibly have been identified by another technique. The PAP method easily confirmed $\alpha$-CD in TC, however, whose biopsy was only slightly abnormal. Although lymphoma cells may derive from the same close as the $\alpha-C D$ protein secreting cells, ${ }^{25}$ lack of secretory differentiation of the lymphoma cell mass would account for the absence of detectable $\alpha$-CD protein in patients with IAL. Abnormal alphachains could not be detected in in vitro cultures of precursor peripheral blood lymphocytes in the cases with $\alpha-C D$ or any of the other patients.

It has been suggested that patients with IPSID may have a defect in cell mediated immunity. ${ }^{1} \mathrm{~A}$ possible deficiency of suppressor T-cells may allow uncontrolled proliferation of plasma cells in response to an antigenic stimulus. By the in vitro techniques described there appeared to be no significant abnormality in cellular immunity in the four PCI patients. Two patients, however, did show a relative decrease in $\mathrm{T}$-helper cells and corresponding increase in T-suppressor cells, the significance of which is uncertain.

Patients HA and SN share many features with a previously described unclassified case. ${ }^{26}$ Both are young and have raised polymerised serum $\operatorname{IgA}$ with raised serum viscosities. Predominance of polymerised serum $\operatorname{IgA}$ is a feature of $\operatorname{IgA}$ myeloma, which is known to predispose to a hyperviscosity syndrome. No evidence of myeloma could be found in any of the cases. Patient HA developed bilateral axillary vein thrombosis in 1982 . Thus the 'benign' cellular infiltrate of the bowel may have serious repercussions and consideration must be given to the consequences of increased serum viscosities in this group of patients, particularly during episodes of diarrhoea to which they are prone.

The patients with PCI and the clinical criteria of IPSID, but without serological evidence of $\alpha$-CD or lymphoma, are an interesting poorly defined subgroup. ${ }^{9}$ As a group these patients have caused confusion as both inflammatory and neoplastic processes have been incriminated. ${ }^{2027} 28$ Despite continuing exposure over a prolonged period to whatever environmental stimuli may be operative, we have not observed any case evolve to overt $\alpha$-CD or lymphoma. We have also been unable to show a basic deficit in cell mediated immunity or nonsecretory alpha-chain production in these patients.

We wish to thank our many colleagues who assisted in the investigation and management of the patients described. Support from the Medical Research Council of South Africa is gratefully acknowledged.

\section{References}

1 WHO Memorandum. Alpha-chain disease and related small intestinal lymphoma. Bull WHO 1976; 54: 615-24.

2 Khojasteh A, Haghshenass M, Haghighi P. Immunoproliferative small intestinal disease. A 'Third World lesion'. N Engl J Med 1983; 308: 1410-5.

3 Seligmann M, Mihaesco E, Frangione B. Studies on alpha chain disease. Ann NY Acad Sci 1971; 190: 487-500.

4 Rambaud JC, Matuchansky C. Alpha-chain disease. Pathogenesis and relation of Mediterranean lymphoma. Lancet 1973; 1: 1430-2.

5 Chantar C, Bootello A, Anaya A, Arenas JJ, Marcos J. Linfoma mediterranea: estudio de diez casos, tres de ellos associados a paraproteinemia. Rev Clin Esp 1978; 148: $47-52$.

6 Nassar VH, Salem PA, Shahid MJ et al. 'Mediterranean abdominal lymphoma' or immunoproliferative small intestinal disease: II. Pathological aspects. Cancer 1978; 41: 1340-54.

7 Rambaud JC. Small intestinal lymphomas and alphachain disease. Clin Gastroenterol 1983; 12: 743-66.

8 Rambaud JC, Galian A, Danon FG et al. Alpha-chain disease without qualitative serum IgA abnormality. Report of two cases, including a 'nonsecretory' form. Cancer 1983; 51: 686-93.

9 Gilinsky NH, Novis BH, Mee AS, Wright JP, Price S, Marks IN. Immunoproliferative small intestinal disease: follow-up of an alpha-chain negative, lymphomafree group. J Clin Gastroenterol 1983; 5: 421-8.

10 Doe WF. Alpha heavy chain disease and related small-intestinal lymphomas. In: Asquith P, ed. Immunology of the gastrointestinal tract. Edinburgh: Churchill Livingstone, 1979: 306-15.

11 Radl J. Light chain typing of immunoglobulins in small samples of biological material. Immunology 1970; 19: $137-49$.

12 Doe WF, Henry K, Hobbs JR, Avery Jones F, Dent $\mathrm{CE}$, Booth CC. Five cases of alpha chain disease. Gut 1972; 13: 947-57.

13 Burns J. Background staining and sensitivity of the unlabelled-antibody-enzyme (PAP) method. Comparison with peroxidase labelled antibody sandwich method using formalin fixed paraffin embedded material. Histochemistry 1975; 43: 291-4.

14 Towbin H, Staehelin T, Gordon J. Electrophoretic transfer of proteins from polyacrylamide gels to nitro- 
cellulose sheets: procedure and some applications. Proc Natl Acad Sci USA 1979; 76: 4350-4.

15 Laemmli UK. Cleavage of structural proteins during the assembly of the head of bacteriophage T4. Nature (London) 1970; 227: 680-5.

16 Beatty DW, Dowdle EB. The effects of kwashiokor serum on lymphocyte transformation in vitro. Clin Exp Immunol 1978; 32: 134-43.

17 Schwartz SA, Choi YS, Shou L, Good RA. Modulatory effects on immunoglobulin synthesis and secretion by lymphocytes from immuno deprived patients. J Clin Invest 1977; 59: 1176-87.

18 Beatty DW, Dowdle EB. Deficiency in kwashiorkor serum of factors required for optimal lymphocyte transformation in vitro. Clin Exp Immunol 1979; 35: 433-42.

19 Jondal M, Holm G, Wigzell H. Surface markers on human $\mathrm{T}$ and B lymphocytes. I. A large population of lymphocytes forming non-immune rosettes with sheep red blood cells. J Exp Med 1972; 136: 207-15.

20 Eidelman S, Parkins R, Rubin CE. Abdominal lymphoma presenting as malabsorption. A clinicopathological study of nine cases in Israel and review of the literature. Medicine (Balt) 1966; 45: 111-37.

21 Bognel JC, Rambaud JC, Modigliani R et al. Etude clinique, anatomo-pathologique et immunochimique d'un nouveau cas de maladie des chaines alpha suivi pendant cinq ans. Rev Eur Clin Biol 1972; 17: 362-74. 22 Galian A, Lecestre MJ, Scotto J, Bognel C, Matuchansky C, Rambaud JC. Pathological study of alpha-chain disease, with special emphasis on evolution. Cancer 1977; 39: 2081-101.

23 Hurez B, Preud'homme JL, Seligmann M. Intracellular 'monoclonal' immunoglobulin in non-secretory human myeloma. J Immunol 1970; 104: 263-4.

24 Rhodes JM, Jewell DP, Janossy G. Alpha-chain disease diagnosed by rectal biopsy. Br Med J 1980; 280: 1043-4.

25 Brouet JC, Mason DY, Danon F et al. Alpha-chain disease; evidence for a common clonal origin of intestinal immunoblastic lymphoma and plasmacytic proliferation. Lancet 1977; 1: 861.

26 Baklien K, Fausa O, Brandtzaeg P, Froland SS, Gjone E. Malabsorption, villous atrophy, and excessive serum IgA in a patient with unusual intestinal immunocyte infiltration. Scand J Gastroenterol 1977; 12: 421-32.

27 Rappaport H, Ramot B, Hulu N, Park JK. The pathology of so-called Mediterranean abdominal lymphoma with malabsorption. Cancer 1972; 29: 1502-11.

28 Lewin KJ, Kahn LB, Novis BH. Primary intestinal lymphoma of 'Western' and 'Mediterranean' type, alpha chain disease and massive plasma cell infiltration. A comparative study of 37 cases. Cancer 1976; 38: 2511-28. 